\title{
IMPACT OF BREED AND FEED RESTRICTION ON CARCASS TRAITS IN THE GROWING RABBITS
}

\author{
S. Ahmed ${ }^{1}$, S.M.A. Sallam², Omnia Essa ${ }^{1}$, T. Rabie ${ }^{1}$ \\ 1- Department of Animal Production and Fish resources, Faculty of Agriculture, Suez Canal University, \\ 41522, Ismailia, Egypt, 2- Department of Animal and Fish Production, Faculty of Agriculture, (El-Shatby) \\ Alexandria University, Alexandria, Egypt
}

Received: 15/9/2019 Accepted: 10/11/2019

SUMMARY

The aim of current study was to evaluate the effect of rabbit' breeds (Red Baladi (RB), and New Zealand White (NZW) breeds), and feed restriction for two weeks (started at 11 and 12 weeks age till they reached 15 weeks of age) on growth performance traits (live body weight and carcass characteristics of growing rabbits). Rabbits were fed ad libitum till they reached 11 weeks of age. Three experimental groups were performed; $1^{\text {st }}$ group was the control $0 \%, 2^{\text {nd }}$ and $3^{\text {rd }}$ groups were fed $60 \%$ and $80 \%$ from ad libitum feeding, respectively. This study resulted in, not only the body weight was affected either by breeds or feed-restriction, but also the feed intake and feed conversion ratio (FCR) were significantly affected. In addition, viability rate (\%) during feed restriction to slaughter was similar in all studied groups. Interestingly, although, feed restriction hadn't effect on scaling a percentage or total edible parts at slaughter, the breeds showed the significant effect on these traits. Furthermore, there were significant effects of breed, feed restriction, and their interactions on both abdominal fat and viscera. Additionally, there were no significant effects of either breeds or feed restriction on kidney weight, but the liver weight affected significantly by interactions between breed and feed restricted. In conclusion, the feed restriction was recommended for two weeks period starting from $11^{\text {th }}$ week of rabbit's age to enhance the growth performance and the carcass characteristics of rabbits.

Keywords: restriction feeding, growth performance, carcass characteristics

\section{INTRODUCTION}

Due to its high meat quality, low fat, in addition to the quantity of meat provided by rabbits, it is a very valuable source of protein for human food (Gidenne et al., 2009 ${ }^{\mathrm{a}}$ ). However, rabbit's breeders faced a big problem due to dam isolation, weaning shock and transition to a new solid feed, which may increase the sensitivity of rabbits to diseases (Gallois et al., 2008). High mortality in rabbit weaning is due to contagious digestive disorders (Marlier et al., 2003), which are widespread in rising rabbits and cause many morbidity and mortality in commercial rabbit farms. Additionally, digestive conditions are minimized by the feed restriction (Gidenne et al., 2009b), which attributable to improve of both nutrients digestibility and feed management (Di Meo et al., 2007; Abdel-Wareth et al., 2015). After that, time of feed restriction, compensated growth depends on the time, rate and style of feed restriction (Di Meo et al., 2007; Gidenne et al., 2009b; Romero et al., 2010; Abdel-Wareth et al., 2015). Feed restriction helps to prevent digestive system diseases that affect young rabbits from weaning to 10 weeks of age (Gidenne et al. 2009c), reduce feed intake, which has a positive effect on feed efficiency (Di Meo et al., 2007; Gidenne et al., 2009c, 2012).

In addition, it reduces carcass fat and improves FCR (Gidenne and Feugier (2009). Accordingly, Di Meo et al. (2007); Gidenne et al. (2012) found that the post-weaning mortality rate was reduced and improved FCR, due to restriction feed regime. Also, Tumova et al. (2003) and Dalle Zotte et al. (2005) observed that restriction feed in the percentage of $60 \%$ was more effective than $80 \%$ to promotes compensatory development by real iminishing and enhances FCR and decreases body fat. Furthermore, feed restriction strategist can be divided into two classes;1- a medium restriction during growth (Gidenne et al. (2003); 2- feed restriction on it at the beginning of growing period followed by ad-labium till slaughtering (Radnai et al., 2005). The pervious feed techniques also enabled to improve feed efficiency, reduce abdominal fat weight in the carcass (Laurence et al., 2003). However, in several other studies, the FCR for rabbits treated with restricted feed was found to be similar to that groups fed ad libitum. Furthermore, low sacrificial weight resulted in feed intake reduction by $4.5 \%$. However, during the real imentation period, the rabbits are compensated growth is as the results of feed intake increasing (Tumova et al. 2016; Gidenne et al., $2009^{\mathrm{a}}$ ). Finally there are no impacts on the sacrificial characteristics result to feed restriction strategies (Larzul et al. 2004; Gidenne et al., 2009a). The aim of the current experiment was to study the effect of two levels of feed restriction $(60 \%$ and $80 \%)$ compared to ad-libitum feeding regime on growth and carcass performance of growing rabbits.

\section{MATERIALS AND METHODS:-}

The present experiment was carried out at the Rabbits Research Farm, Department of Animal Production, Faculty of Agriculture, Suez Canal University, Ismailia, Egypt during the period from September 2017 to February 2018. 
Experimental design and rabbitry management:

Two breed were selected (73 animals of each of Red Baladi and New Zealand White breeds). Rabbits weaned at 28 day were divided into three groups; each group has 16 of animals and kept individually in galvanized wire batteries with automatic nipple drinkers and provided with separated feeders. Lighting system was sixteen $\mathrm{hr}$ light/eight hr dark in the rabbitry during experimental period. The rabbits were apparently healthy and free of any external parasites or skin diseases. Pre-experiment was conducted to carry out the amount of ad-libitum feed to calculate the feed restriction levels upon the total daily feed intake. The feed restriction started at $11^{\text {th }}$ week for two weeks (ad-libitum a control, 60\% and $80 \%$ from ad-libitum), while at the beginning $13^{\text {th }}$ week of age the treated groups were fed ad-libitum feeding continuously till the slaughter at 15 weeks of age. The calculated chemical composition of the diet were $18 \%$ crude protein, $2.69 \%$ fat, $12.39 \%$ crude fiber and $2738 \mathrm{kcal}$ digestible energy $/ \mathrm{kg}$ diet according to NRC (1984).

\section{Performance and carcass traits: \\ Growth traits:}

At the early morning on the same day of the each week rabbits were individually weighed weekly. Then the body weight gain was calculated, feed intake $(\mathrm{g})$, feed conversion ratio ( $\mathrm{kg}$ feed $/ \mathrm{kg}$ gain) and mortality rate was recoded.

\section{Slaughter traits:}

At the end of the $15^{\text {th }}$ week of age, the rabbits were individually weighed. Six rabbits per treatment were selected, kept off feed for $12 \mathrm{~h}$ and slaughtered to evaluate the carcass traits after removing both abdominal fat and viscera. The legs, skin, fur, heart, liver and kidneys were individually weighed. The carcass weight and scaling of edible parts was expressed as a percentage of live body weight.

\section{European Efficiency factors (EEf):}

European Efficiency factors (EEf) was calculated as the following:

$\mathrm{EEF}=($ weight gain $(\mathrm{g}) /$ age day $) \times($ viability rate \%/ feed conversion ratio ( $\mathrm{kg}$ feed/ $\mathrm{kg}$ gain): 10, according to Nilipour, (1998).

\section{Statistical analysis:}

Data were statistically analyzed using General Linear Models Procedure of the SPSS 20 program (2015). The following model was used to study the effect of main factors and interaction between feed restriction (FR) and Breed (B) on recorded traits as follows:-

$\mathrm{Y}_{\mathrm{ijk}}=\mu+\mathrm{F}_{\mathrm{i}}+\mathrm{B}_{\mathrm{j}}+(\mathrm{FR})_{\mathrm{ij}}+\mathrm{e}_{\mathrm{ijk}}$

Where :Yijk=An observation $\mu=$ overall mean ; $F_{i}=$ effect of FR level; $I=(1,2$ and 3$) ; B_{j}=$ effect of breed; $\mathrm{j}=(1$ and 2$) ; \mathrm{FR}_{\mathrm{ij}}=$ effect of interaction between FR and B (ij $(1,2 \ldots 6)$; and ejik = Experimental error. The Differences means among treatments were subjected to Duncan' s Multiple Range- test (Duncan, 1955).

\section{RESULTS}

Growth Performance:

Effect of feed restriction in body weight:

The effect of the breed and feed restriction levels on body weights during feed restriction (11and $12^{\text {th }}$ weeks of age) and the free feeding period from 13 to $15^{\text {th }}$ weeks of age and their interaction presented in Table (1). The results revealed that although feed restriction levels had significantly $(\mathrm{P} \leq 0.05)$ negative effect on body weight during feed restriction. It had significantly $(\mathrm{P} \leq 0.05)$ positive effect after feed restriction. However, there was significant interaction effect between breed and the level of feed restriction levels on body weight $(\mathrm{P} \leq 0.05)$ at 13 and $14^{\text {th }}$ weeks. At the beginning of feed restriction, a drop in rabbits growth was observed accompanied by reducing of feed intake in restricted rabbits during the feed restriction period, when animals are again fed ad libitum, compensatory growth is observed during the real imentation period, and its related with level of feed restriction. These results are symmetrical with many reports of Tumová et al., 2003; Yakubu et al., 2007; Gidenne and Feugier, 2009; Gidenne et al., 2009b; Gidenne et al., 2012;Oliveira et al., 2012; Alabiso et al., 2016; Tumova, Volek et al., 2016 and Birolo et al., 2017). Although, both breed had a significant effects and restriction feed treatments on body weight, which in agreement with Tumová et al., 2003; Yakubu et al., 2007 and Gidenne et al., 2012), where they found no significant effects and explained it by the differences of the levels and duration of feed restriction treatments (Gidenne et al., 2012).

Effect of feed restriction on feed intake, feed conversion and mortality rate (\%):

The difference of the feed intake was significantly lower in the $60 \%$ restriction feeding (FR1) group than the control group (FR0) $(\mathrm{P}<0.05)$. Total feed intake of rabbits was not significantly $(\mathrm{P}>0.05)$ differed between two breeds, which might be due to equality total feed intake among treatments. Moreover, FCR ( $\mathrm{kg}$ feed $/ \mathrm{kg}$ gain) and EEf were significantly lower in the control group (FR0) than in the (FR1) group $(\mathrm{P}<0.05)$, with no significant effect of the breed $(\mathrm{P}<0.05)$ presented in Table (3). In current study, feed intake was similar for both the determination rabbits and the ad libitum groups agrees with those of Tumova et al. (2003); Romero et al. 2010), where different feed intake results might be related to feeding behaviors (Gidenne et al., 2012). In addition Gidenne et al. (2009a) found that the compensatory growth was not associated with evolved feed conversion in contradictory with current results where FCR was increasing in restricted feed groups compared to ad-libitum group. Concerning the mortality rate $(\%)$, during feed restriction to slaughter was similar with no records of mortality in the treatment groups. Ebeid et al. (2012) reported that the feed restriction had no effect on mortality rate of the rabbits. On contrast, Gidenne et al., (2012) stated that restriction period (for 2 or 3 weeks) decreased 
mortality rate and morbidity from digestive problems. Morover, the duration of restriction feed had no influence on mortality percentage as reported by Gidenne et al.(2003); Yakubu et al.(2007).

Table 1. Effect of breed, feed restriction and their interaction on body weight (g) at different age

\begin{tabular}{|c|c|c|c|c|c|c|c|c|c|c|c|}
\hline \multirow{2}{*}{ Weeks } & \multicolumn{2}{|c|}{ Breed } & \multicolumn{3}{|c|}{ FR } & \multicolumn{6}{|c|}{ Inter. Effects: B*FR } \\
\hline & BR & NZW & FR0 & FR1 & FR2 & $\mathrm{BR}^{*} \mathrm{FR} 0$ & BR*FR1 & BR*FR2 & NZW*FR0 & $\mathrm{NZW}^{*} \mathrm{FR} 1$ & $\mathrm{NZW} * \mathrm{FR} 2$ \\
\hline W11 & $\begin{array}{c}1274.7^{\mathrm{b}} \\
\pm 4.0\end{array}$ & $\begin{array}{c}1380.4^{\mathrm{a}} \\
\pm 4.0\end{array}$ & $\begin{array}{c}1401.2^{\mathrm{a}} \\
\pm 4.9\end{array}$ & $\begin{array}{c}1275.5^{\mathrm{ab}} \\
\pm 4.8\end{array}$ & $\begin{array}{c}1306 .{ }^{0 \mathrm{~b}} \\
\pm 4.9\end{array}$ & $\begin{array}{c}1349.6^{\mathrm{a}} \\
\pm 6.9\end{array}$ & $\begin{array}{c}1215.3^{\mathrm{a}} \\
\pm 6.9\end{array}$ & $\begin{array}{c}1258.9^{\mathrm{a}} \\
\pm 6.9\end{array}$ & $\begin{array}{c}1452.6^{\mathrm{a}} \\
\pm 6.9\end{array}$ & $\begin{array}{c}1335.6^{\mathrm{a}} \\
\pm 6.8\end{array}$ & $\begin{array}{c}1353.0^{\mathrm{a}} \\
\pm 7.0\end{array}$ \\
\hline W12 & $\begin{array}{c}1336.3^{\mathrm{b}} \\
\pm 5.3\end{array}$ & $\begin{array}{c}1454.1^{\mathrm{a}} \\
\pm 5.3\end{array}$ & $\begin{array}{c}1602.9^{\mathrm{a}} \\
\pm 6.4\end{array}$ & $\begin{array}{c}1267.4^{\mathrm{ab}} \\
\pm 6.4\end{array}$ & $\begin{array}{c}1315.3^{\mathrm{b}} \\
\pm 6.5\end{array}$ & $\begin{array}{c}1551.4^{\mathrm{a}} \\
\pm 9.1\end{array}$ & $\begin{array}{c}1196.0^{\mathrm{a}} \\
\pm 9.1\end{array}$ & $\begin{array}{c}1261.7^{\mathrm{a}} \\
\pm 9.1\end{array}$ & $\begin{array}{c}1654.8^{\mathrm{a}} \\
\pm 9.1\end{array}$ & $\begin{array}{c}1338.1^{\mathrm{a}} \\
\pm 8.9\end{array}$ & $\begin{array}{c}1368.8^{\mathrm{a}} \\
\pm 9.3\end{array}$ \\
\hline W13 & $\begin{array}{c}1631.3^{\mathrm{b}} \\
\pm 4.9\end{array}$ & $\begin{array}{c}1789.8^{\mathrm{a}} \\
\pm 4.9\end{array}$ & $\begin{array}{c}1805.7^{\mathrm{a}} \\
\pm 6.0\end{array}$ & $\begin{array}{c}1652.3^{\mathrm{ab}} \\
\pm 6.0\end{array}$ & $\begin{array}{c}1673.6^{\mathrm{b}} \\
\pm 6.1\end{array}$ & $\begin{array}{c}1753.7^{\mathrm{a}} \\
\pm 8.5\end{array}$ & $\begin{array}{c}1556.7^{\mathrm{ab}} \\
\pm 8.5\end{array}$ & $\begin{array}{c}1583.4^{\mathrm{b}} \\
\pm 8.5\end{array}$ & $\begin{array}{c}1857.7^{\mathrm{a}} \\
\pm 8.5\end{array}$ & $\begin{array}{c}1747.9^{\mathrm{ab}} \\
\pm 8.4\end{array}$ & $\begin{array}{c}1763.9^{\mathrm{b}} \\
\pm 8.7\end{array}$ \\
\hline W14 & $\begin{array}{c}1960.1^{\mathrm{b}} \\
\pm 3.7\end{array}$ & $\begin{array}{c}2122.3^{\mathrm{a}} \\
\pm 3.7\end{array}$ & $\begin{array}{c}2005.7^{\mathrm{ab}} \\
\pm 4.6\end{array}$ & $\begin{array}{c}2056.9^{\mathrm{b}} \\
\pm 4.5\end{array}$ & $\begin{array}{c}2061.0^{\mathrm{a}} \\
\pm 4.63\end{array}$ & $\begin{array}{c}1954.8^{\mathrm{ab}} \\
\pm 6.5\end{array}$ & $\begin{array}{c}1960.8^{\mathrm{b}} \\
\pm 6.5\end{array}$ & $\begin{array}{c}1964.6^{\mathrm{a}} \\
\pm 6.5\end{array}$ & $\begin{array}{c}2056.6^{\mathrm{ab}} \\
\pm 6.5\end{array}$ & $\begin{array}{c}2153.0^{b} \\
\pm 6.3\end{array}$ & $\begin{array}{c}2157.4^{\mathrm{a}} \\
\pm 6.6\end{array}$ \\
\hline W15 & $\begin{array}{c}2156.7^{\mathrm{b}} \\
\pm 6.7\end{array}$ & $\begin{array}{c}2411.4^{\mathrm{a}} \\
\pm 6.7\end{array}$ & $\begin{array}{c}2234.8^{\mathrm{ab}} \\
\pm 8.2\end{array}$ & $\begin{array}{c}2306.8^{\mathrm{b}} \\
\pm 8.1\end{array}$ & $\begin{array}{c}2310.6^{\mathrm{a}} \\
\pm 8.3\end{array}$ & $\begin{array}{c}2125.6^{\mathrm{a}} \\
\pm 11.6\end{array}$ & $\begin{array}{c}2161.2^{\mathrm{a}} \\
\pm 11.6\end{array}$ & $\begin{array}{c}2183.3^{\mathrm{a}} \\
\pm 11.6\end{array}$ & $\begin{array}{c}2344.1^{\mathrm{a}} \\
\pm 11.6\end{array}$ & $\begin{array}{c}2452.4^{\mathrm{a}} \\
\pm 11.3\end{array}$ & $\begin{array}{c}2437.8^{\mathrm{a}} \\
\pm 11.8\end{array}$ \\
\hline
\end{tabular}

RB: Red Baladi Breed; NZW: New Zealand White Breed; FR0: control diet; FR1:60\% of the diet; FR2:80\% of the Diet; B *FR: Interaction between breed and feed; \pm : standard error of the mean;a-b Means within the same row with the different superscript letter are significantly different $(\mathrm{p}>.05)$.

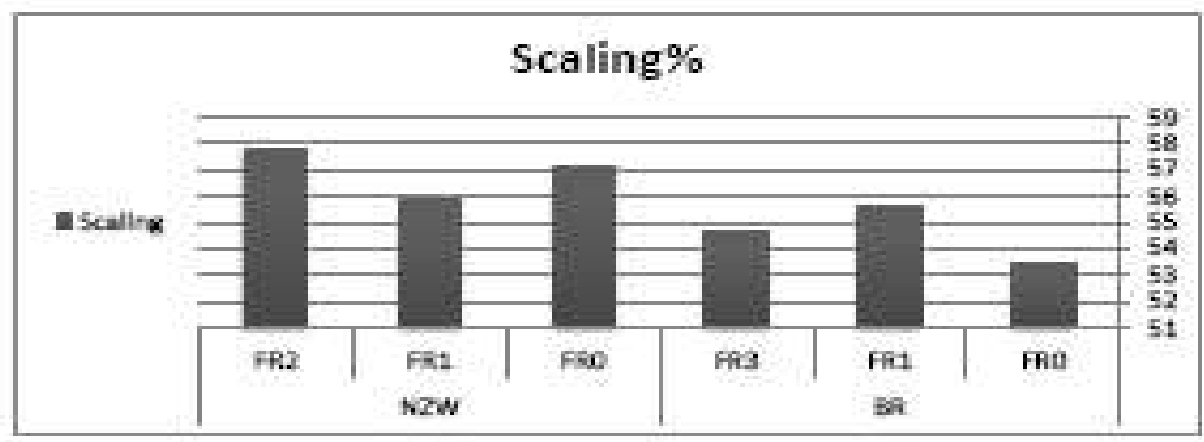

Figure 1. Effect of breed and feed restriction in scaling (\%).

\section{Effect of feed restriction in carcass traits:}

The carcass traits are shown in Table $(2,3)$. Significant effect of breed, feed restriction, and their interaction for 15 weeks of age were noticed on the carcass weight. The carcass, heart, fat abdominal, viscera, skin and fur weights were affected significantly $(\mathrm{P}<0.05)$ by breed. However, the levels of feed restriction were significantly $(\mathrm{P}<0.05)$ affected the heart, the fat abdominal, the skin and fur weights $(\mathrm{g})$. Moreover, interaction effects between breed and levels of restriction feeding were significantly $(\mathrm{P}<0.05)$ impacted on the heart, the liver, the fat abdominal and viscera weights. The carcass characteristics are important factors to evaluate the feeding programs (Ledin 1984), as with growth performance, the feed restriction can change body composition, and carcass weights. Differences in rabbit carcass traits have been observed under high level or long limited periods (Gidenne et al. 2009a; Metzger et al. 2009) and differences in the development of carcass parts with increasing age (Pascual et al., 2008).

The current results indicated that group with the highest level of feed restriction had the lowest body weight during the restriction of feed period, but at slaughter the differences between levels of feeding were not significant, which agreed with Tumov et al.
(2006); Bovera et al. (2013); Birolo et al. (2017). On contrast, Olajide and Ayoola, (2012); Chodova et al. (2016) found lower carcass weights in the feed restriction group than in an ad-libitum group, which are not consistent with current study. On current study feed restriction had not effect on scaling percentage at slaughter, as was also observed by Tumov_a et al. (2003, 2006); Oliveira et al. (2012); Alabiso et al. (2016). However, the level of feed restriction resulted in a lower percentage in scaling in restriction feeding rabbits groups (Chodov et al., 2016), which in harmony with the results of the current study. The non-significant effect of feed restriction in scaling $\%$ and total edible parts at slaughter was in agreement with many previous studies (Combes et al.,2003; Tůmova et al.,2003 and Boisot et al.,2004). On the other hand, Matics et al. (2008); Metzger et al. (2009) had observed a few effect of feed restriction. A significantly higher proportion of legs in ad-libitum fed group compared with restriction fed groups were stated by Combes et al. (2003), which are in contrast with the current results. Moreover, the importance of feed restriction is reducing of total amount of feed intake, in such way improve the carcass composition and reduced the abdominal fat, which in the same direction of the 
results reported by Metzger et al., 2009; Chodov et al. 2016).

Table 2. Effect of feed restriction, breed on carcass traits at slaughter age (15) weeks (g)

\begin{tabular}{cccccc}
\hline \multirow{2}{*}{ Traits } & \multicolumn{3}{c}{ Breed } & \multicolumn{4}{c}{ FR } \\
\cline { 2 - 6 } & BR & NZW & FR0 & FR1 & FR2 \\
\hline Carcass $(\mathrm{g})$ & $1122.5^{\mathrm{b}} \pm 10.9$ & $1324.8^{\mathrm{a}} \pm 10.9$ & $1210.8^{\mathrm{a}} \pm 13.3$ & $1226.2^{\mathrm{a}} \pm 13.2$ & $1233.9^{\mathrm{a}} \pm 13.5$ \\
Heart(g) & $7.6^{\mathrm{b}} \pm 0.3$ & $8.9^{\mathrm{a}} \pm 0.3$ & $9.5^{\mathrm{a}} \pm 0.4$ & $6.7^{\mathrm{ab}} \pm 0.4$ & $8.6^{\mathrm{b}} \pm 0.4$ \\
Liver(g) & $80.5^{\mathrm{a}} \pm 2.1$ & $75.8^{\mathrm{a}} \pm 2.1$ & $80.4^{\mathrm{a}} \pm 2.6$ & $79.4^{\mathrm{a}} \pm 2.5$ & $74.7^{\mathrm{a}} \pm 2.6$ \\
Kidneys(g) & $14.2^{\mathrm{a}} \pm 0.4$ & $14.9^{\mathrm{a}} \pm 0.4$ & $15.4^{\mathrm{a}} \pm 0.5$ & $14.3^{\mathrm{a}} \pm 0.5$ & $13.9^{\mathrm{a}} \pm 0.5$ \\
Head(g) & $91.8^{\mathrm{a}} \pm 0.8$ & $97.4^{\mathrm{a}} \pm 0.8$ & $96.1^{\mathrm{a}} \pm 0.9$ & $93.2^{\mathrm{a}} \pm 0.9$ & $94.8^{\mathrm{a}} \pm 0.9$ \\
Fat Abdominal(g) & $7.9^{\mathrm{b}} \pm 0.2$ & $8.5^{\mathrm{a}} \pm 0.2$ & $12.7^{\mathrm{a}} \pm 0.2$ & $3.7^{\mathrm{c}} \pm 0.2$ & $8.2^{\mathrm{b}} \pm 0.2$ \\
Viscera(g) & $357.9^{\mathrm{a}} \pm 5.7$ & $324.7^{\mathrm{b}} \pm 5.7$ & $350.4^{\mathrm{a}} \pm 7$ & $338.4^{\mathrm{a}} \pm 6.9$ & $335.2^{\mathrm{a}} \pm 7.1$ \\
The legs(g) & $71.8^{\mathrm{a}} \pm 0.9$ & $74.8^{\mathrm{a}} \pm 0.9$ & $74.6^{\mathrm{a}} \pm 1$ & $72.1^{\mathrm{a}} \pm 1$ & $73.1^{\mathrm{a}} \pm 1.1$ \\
Skin and fur(g) & $271.3^{\mathrm{b}} \pm 4.5$ & $279.5^{\mathrm{a}} \pm 4.5$ & $284.4^{\mathrm{a}} \pm 5.5$ & $257.9^{\mathrm{ab}} \pm 5.4$ & $283.8^{\mathrm{b}} \pm 5.5$ \\
Scaling $(\%)$ & $54.6^{\mathrm{a}}$ & $56.9^{\mathrm{a}}$ & $55.3^{\mathrm{a}}$ & $56.2^{\mathrm{a}}$ & $55.7^{\mathrm{a}}$ \\
Total edible parts & $1316.7^{\mathrm{a}} \pm 11$ & $1521.9^{\mathrm{a}} \pm 11.1$ & $1412.1^{\mathrm{a}} \pm 13.5$ & $1419.9^{\mathrm{a}} \pm 13.4$ & $1425.9^{\mathrm{a}} \pm 13.7$ \\
\hline
\end{tabular}

RB: Red Baladi Breed; NZW: New Zealand Breed;FR0: control diet; FR1: 60\% of the diet; FR2: 80\% of the diet; \pm : standard error of the mean;

${ }^{a-c}$ Means within the same row with the different superscript letter are significantly different $(p>.05)$.

Table 3. interaction effects between breed and feed restriction on feed intake (g), feed conversion ratio (kg feed/kg gain), economic efficiency factors and carcass traits at slaughter age (15) weeks (g)

\begin{tabular}{|c|c|c|c|c|c|c|}
\hline \multicolumn{7}{|c|}{ Inter. Effects* FR } \\
\hline Traits & BR*FR0 & BR*FR1 & BR*FR2 & NZW*FR0 & NZW*FR1 & NZW*FR2 \\
\hline Carcass (g) & $1083.3^{\mathrm{a}} \pm 18.9$ & $1147.5^{\mathrm{a}} \pm 18.9$ & $1136.6^{\mathrm{a}} \pm 18.9$ & $1338.3^{\mathrm{a}} \pm 18.9$ & $1320.4^{\mathrm{a}} \pm 19.8$ & $1315.8^{\mathrm{a}} \pm 18.5$ \\
\hline Heart $(g)$ & $8.6^{\mathrm{a}} \pm 0.6$ & $6.8 \mathrm{a}^{\mathrm{b}} \pm 0.6$ & $7.5^{\mathrm{b}} \pm 0.6$ & $10.3^{\mathrm{a}} \pm 0.6$ & $10.3^{\mathrm{b}} \pm 0.6$ & $5.9^{\mathrm{ab}} \pm 0.6$ \\
\hline Liver(g) & $88.1^{\mathrm{a}} \pm 3.6$ & $76.1^{\mathrm{ab}} \pm 3.6$ & $77.4^{b} \pm 3.6$ & $72.8^{\mathrm{ab}} \pm 3.6$ & $73.3^{\mathrm{b}} \pm 3.7$ & $81.40^{\mathrm{a}} \pm 3.5$ \\
\hline Kidneys(g) & $15.1^{\mathrm{a}} \pm 0.75$ & $13^{\mathrm{a}} \pm 0.8$ & $14.6^{\mathrm{a}} \pm 0.8$ & $15.8^{\mathrm{a}} \pm 0.8$ & $14.9^{\mathrm{a}} \pm 0.8$ & $14.1^{\mathrm{a}} \pm 0.7$ \\
\hline Head(g) & $94.4^{\mathrm{a}} \pm 1.3$ & $90.9^{\mathrm{a}} \pm 1.3$ & $90.3^{\mathrm{a}} \pm 1.3$ & $97.8^{\mathrm{a}} \pm 1.3$ & $98.7^{\mathrm{a}} \pm 1.3$ & $95.9^{\mathrm{a}} \pm 1.3$ \\
\hline Fat abdominal $(\mathrm{g})$ & $12.3^{\mathrm{a}} \pm 0.3$ & $7.1^{b} \pm 0.3$ & $4.5^{c} \pm 0.3$ & $13.1^{\mathrm{a}} \pm 0.3$ & $9.3^{b} \pm 0.3$ & $3^{c} \pm 0.3$ \\
\hline $\operatorname{Viscera}(\mathrm{g})$ & $387.6^{\mathrm{a}} \pm 9.9$ & $344.6^{\mathrm{b}} \pm 9.9$ & $341.6^{\mathrm{ab}} \pm 9.9$ & $313.1^{\mathrm{ab}} \pm 9.9$ & $325.8^{\mathrm{b}} \pm 10.1$ & $335.2^{\mathrm{a}} \pm 9.7$ \\
\hline $\operatorname{legs}(g)$ & $72.6^{\mathrm{a}} \pm 1.5$ & $70.3^{\mathrm{a}} \pm 0.8$ & $72.4^{\mathrm{a}} \pm 1.5$ & $76.5^{\mathrm{a}} \pm 1.5$ & $76.0^{\mathrm{a}} \pm 1.5$ & $71.9^{\mathrm{a}} \pm 1.5$ \\
\hline Skin, fur $(\mathrm{g})$ & $288.4^{\mathrm{a}} \pm 7.7$ & $281.3^{\mathrm{a}} \pm 7.7$ & $244.1^{\mathrm{a}} \pm 7.7$ & $280.4^{\mathrm{a}} \pm 7.7$ & $286.4^{\mathrm{a}} \pm 7.9$ & $271.6^{\mathrm{a}} \pm 7.6$ \\
\hline Scaling $(\%)$ & $53.5^{\mathrm{a}}$ & $55.6^{\mathrm{a}}$ & $54.7^{\mathrm{a}}$ & $57.1^{\mathrm{a}}$ & $55.9^{\mathrm{a}}$ & $57.8^{\mathrm{a}}$ \\
\hline T. edible parts & $1289.4^{\mathrm{a}} \pm 19.1$ & $1334.3^{\mathrm{a}} \pm 19.1$ & $1326.5^{\mathrm{a}} \pm 19.1$ & $1534.9^{\mathrm{a}} \pm 19.1$ & $1517.5^{\mathrm{a}} \pm 19.5$ & $1513.2^{\mathrm{a}} \pm 18.7$ \\
\hline T.F.I & $7175^{\mathrm{a}}$ & $6895^{b}$ & $6615^{\mathrm{ab}}$ & $7175^{\mathrm{a}}$ & $6895^{\mathrm{b}}$ & $6615^{\mathrm{ab}}$ \\
\hline FCR & $3.37^{\mathrm{a}}$ & $3.07^{\mathrm{b}}$ & $2.82^{\mathrm{ab}}$ & $3.04^{\mathrm{a}}$ & $2.82^{b}$ & $2.88^{\mathrm{ab}}$ \\
\hline E.E.f & $5.9^{\mathrm{ab}}$ & $6.7^{\mathrm{b}}$ & $7.3^{\mathrm{a}}$ & $7.2^{\mathrm{ab}}$ & $8.3^{\mathrm{a}}$ & $8.1^{\mathrm{b}}$ \\
\hline
\end{tabular}

RB: Red Baladi Breed; NZW: New Zealand Breed;FR0: control diet; FR1:60\% of the diet. FR2:80\% of the diet *FR: Interaction between breed and feed; T.F.I: total feed intake (g) from (4) weeks to slaughter; FCR: Feed conversion ratio (kg feed/kg gain) at slaughter; (EEf):Economic Efficiency factor

On the other hand, other studies showed that feed restriction has relatively affected on relative organ weights (Matics et al., 2008; Metzger et al., 2009), although the weights of internal organs (liver and kidneys) were not affected at the current study using feeding restriction, which inconsistent with Tumová et al., 2007, while the heart weight was affected by restriction feeding as also found by Tumová et al.(2006). These results can attributed to priority is given to the internal organ maintenance in periods of feed scarcity, the lower protein content in the cells, accompanied by depression in cell size due to feed restriction, which resulted in the heart weight will be reduced than normal.

\section{CONCLUSION}

Feed restriction for two weeks starting from $11^{\text {th }}$ week of age was recommended because it had a positive and economical effects on rabbits performance and carcass traits.

\section{REFERENCES}

Abdel-Wareth, A.A., A.S. Kehraus, A.H.H. Ali, Z.S.H. Ismail and K.H. Sudekum, 2015. Effects of temporary intensive feed restriction on performance, nutrient digestibility and carcass criteria of growing male Californian rabbits. Arch. Anim. Nutr., 69: 69-78. https://doi.org/10.1080/1745039X.2014.1002672.

Alabiso, M., A. Digrigoli Mazza, F.G. Maniaci, F.B. Vitale and A. onanno, 2016. A 3-weekfeed restriction after weaning as an alternative to a medicated diet: effects on growth, health, carcass and meat traits of rabbits of two genotypes. Animal. 21:1-9.

Birolo, M., A. Trocino, M. Tazzoli and G. Xiccato, 2017. Effect of feed restriction and feeding plans 
on performance, slaughter traits and body composition of growing rabbits. World Rabbit Sci. 25:113-122.

Boisot, P., J. Duperray, X. Dugenetais and A. Guyonvarch, 2004. Interes to fhydric restriction times of 2 and 3 hours per day to induce feed restriction ingrowingrabbits.In:Proc.8thWorldRabbitCongres s,September,710,Puebla, Mexico. P.759-764.

Bovera, F., A. Lestingi, G. Piccolo, F. Iannaccone, Y.A. Attia and A. Tateo, 2013. Effects of water restriction on growth performance feed nutrient digestibility, carcass and meat traits of rabbits. Animal. 7:1600-1606.

Chodova, D., E. T ${ }^{\circ}$ umova, Z . Volek, V. Skrivanov and J. Vlckova, 2016.The effect of one-week intensive feed restriction and age on the carcass composition and meat quality of growing rabbits. Czech J. Anim Sci. 61:151-158.

Combes, S., T. Gidenne, N. Jehl and A. Feugier, 2003.Impact of a quantitative feed restriction on meat guality of the rabbit. In: Proc. Cost Action848,Working Group 5 Meat Quality, September 25-27, Prague, Czech Republic. 45 p.

Dalle Zotte, A., H. Reignon and J. Ouyayoun, 2005. Effect of feed rationing during post-weaning growth on meat quality, muscle energy metabolism and fibre properties of Biceps femoris muscle in the rabbit. Meat Sci. 70:301-306.

Di Meo, C., F. Bovera, S. Marono, N. Vella and A. Nizza, 2007. Effect of feed restriction on performance and feed digestibility in rabbits. It. J. Anim. Sci., 6: 765767.doi:10.4081/ijas.2007.1s.765.

Duncan, D. B.,1955 .Multiple range and multiple Ftest, Biometrics, 11: 1-42.38.

Eibed, C., K. Kurtos, A. Kenessey, G. Virag and Z. Szendro, 2001. Effect of different feed restrictions during rearing on reproduction performance in rabbit does. World Rabbit Science 9: 9-14.

Gallois, M., L.I. Le Hu€erou-Luron, FortunLamothe, J.P. Lalles and T. Gidenne, 2008. Adaptability of the digestive function according to age at weaning in the rabbit: I. Effect on feed intake and digestive functionality. Animal. 2:525535.

Gidenne, T and A. Feugier, 2009. Feed restriction strategy in the growing rabbit. 1. Impact on digestion, rate of passage and microbial activity. Animal. 3:501-508.

Gidenne, T., A. Feugier, N. Jehl, P. Arveus, P. Boisot, C. Briens, E. Corrent, H. Fortune, S. Montessuy and S. Verdelhan, 2003. Un rationnement alimentaire quantitatif post-sevrage permet de réduire la fréquences des dierrhées, sansdegradation importante des performances de croissance: résultat d'une étudemulti-site. In: Proc. 10émes Journ. Rech. Cunicole, 2003 November, Paris, France, 29-32.

Gidenne,T., S. Combes, A. Feugier, N. Jehl, P. Arveux, P. Boisot, C. Briens and E. Corrent, 2009a. Feed restriction strategy in the growing rabbit. 2. Impact on digestive health, growth and carcass characteristics. Animal. 3:509-515.

Gidenne, T., S. Murr, A. Travel, E. Corrent, C. Foubert, K. Bebin, L. Mevel, G. Rebours and B. Renouf, 2009b. Effets du niveau de rationnement et du mode de distribution de l'aliment sur les performances et les troubles digestifs postsevrage $\mathrm{du}$ lapereau. Premiers re' sultats d'une e' tude concerte'e du re' seau GEC. Cuniculture Magazine 36, 65-72.

Gidenne,T., C. Bannelier, S. Combes and L. Fortun Lamothe, 2009c. Interaction between the energetic feed concentration and the restriction strategy -impact on feeding behaviour, growth and health of the rabbit. 13e'me Journe' esde Recherches Cunicoles, Le Mans, France, pp. 6366.

Gidenne, T., S. Combes and L. Fortun-Lamothe, 2012.Feedin take limitation strategies for the growing rabbit: effect on feeding behaviour, welfare, performance, digestive physiology and health: a review. Animal. 6:1407-1419.

Larzul, C., R.G .Th_ebault and D. Allain, 2004. Effect of feed restriction on rabbit meat quality of the Rex du Poitou(VR ). Meat Sci. 67:479484.Larzul C, Th_ebault RG, Allain D. 2004.

Laurence, D., L.H. Isabelle and G. THIERRY, 2003. Digestive tract development in rabbit according to dietary energetic source: correlation between whole tract digestion, pancreatic and intestinal enzymatic activities. Comparative Biochemistry and Physiology, v.135, p.443-455, 2003.

Ledin, I., 1984. Effect of restricted feeding and realimentation on compensatory growth, carcass composition and organ growth in rabbit. Ann. Zootech. 33: 33-50.

Marlier, D., R. Dewree, V. Delleur, D. Licois, C. Lassence, A. Poulipoulis and H.V. Indevogel, 2003. A review of the major causes of digestive disorders in the European rabbit. Annales de Medecine Veterinaire 147, 385-392.

Matics, Z., S.A. Dalle Zotte, I. Radnai, M. Kovács, S.Z. Metzger and Z.S. Szendr1, 2008. Effect of restricted feeding after weaning on the productive and carcass traits of growing rabbits. 9th World Rabbit Congress, June 10-13, 2008, Verona, Italy.

Metzger, S., Z. Szendro, M .Bianchi, I .Hull, H .Febel, L .Maertens, C. Cavani, M. Petracci, I. Radnai and E. Biro Nemeth, 2009. Effect of energy restriction in interaction with genotype on the performance of growing rabbits: II. Carcasstrait and meat quality. Livest Sci. 126:221-228.

Nilipours, A.H., 1998. Nunbres for successful poultry production world poulty, 14:26-28.

NRC, 1984. National Research Council. Nutrient Requriments of Rabbits. The 2nd Revised Edition. National Academy of Science. Washington. D.C. USA. 
Olajide, A.A and O.A. Ayoola, 2012. Effect of feed restriction on performanceof growing rabbits. Revista Brasileira de Zootecnia. 41:1463-1467.

Oliveira, M.C., R.P. DaSilva, L.S. Araujo, V.R. DaSilva, E.A. Bento and D.M. Silva, 2012. Effect of feed restriction on performance of growing rabbits. Revista Brasileira de Zootecnia. 41:14631467.

Pascual, M., M .Pla and A. Blasco, 2008.Effect of selection for growth rate on relative growth in rabbits. J Anim Sci. 86: 3409-3417..

Radnai, I., Zs.Szendrı, R. Romvári, Zs.Matics and N. Wolf, 2005. Effect of restricted feeding on productive and carcass traits of rabbits. In: Proc. 17th Hung. Conf. Rabbit Prod., 2005 May, Kaposvár, Hungary, 39-45 (in Hung.).

Romero, C., S. Cuesta, J.R. Astillero, N. Nicodemus and C.D. Blas, 2010. Effect of early feed restriction on performance and health status in growing rabbits slaughtered at $2 \mathrm{~kg}$ live-weight. World Rabbit Sci., 18: 211218.https://doi.org/10.4995/wrs.2010.778.

SPSS., 2015. SPSS User's Guide Statistics. Ver. 20. Copyright SPSS Inc., USA.
Tumova, E., V .Skrivanova and M. Skrivan, 2003. Effect of restricted feeding timeand quantitative restriction in growing rabbits. Arch. Gefl€ugelkunde. 67:182-190.

Tumova, E, L Zita and L._Stolc, 2006. Carcass quality in restrictedand ad libitum fed rabbits. Czech J Anim Sci. 51:214-219.

Tumová, E., L. Zita, V. Skřivanová, A. Fučíková, M. Skřivan, and M. Burešová, 2007. Digestibility of nutrients, organ development and blood picture in restricted and ad libitum fed, 2nd Ed. CABI, Wallingford, pp. 151-162.

Tumova, E., Z .Volek, D .Chodov_a, H .H€artlov_a, $\mathrm{P}$.Makovick y,J .Svobodova ,TA .Ebeid andL.Uhl_1_rov_a, 2016. The effect of 1-week feed restriction on performance, digestibility ofnutrients and digestive system development inthe growingrabbit. Animal. 10:1-9.

Yakubu, A., A.E. Salako, A.O. Ladokun, M.M. Adua and T.U.K. Bature, 2007. Effects of feed restriction on performance, carcass yield, relative organ weight sand some linear body measurements of weaner rabbits. Pakistan Journal of Nutrition 6 (4): 39.

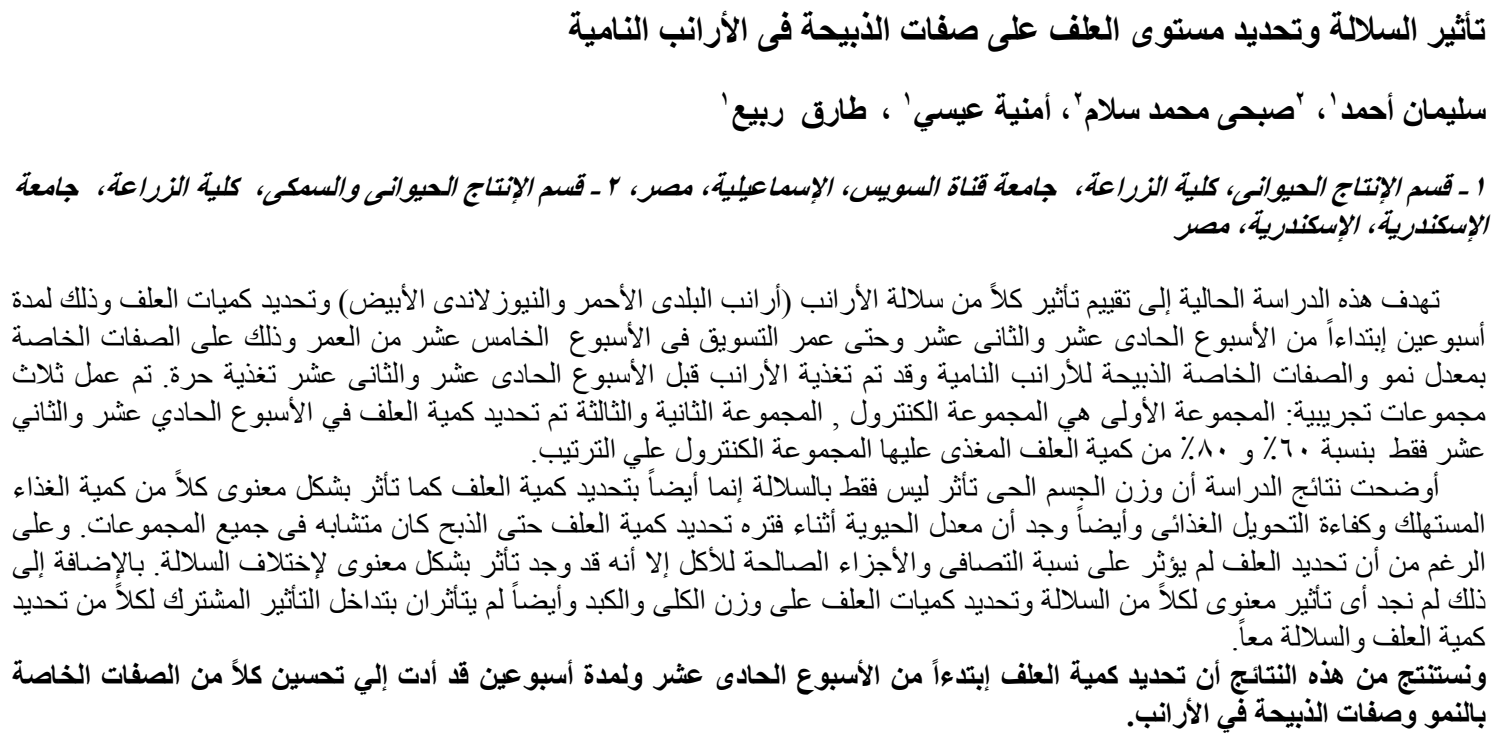

